\title{
Temporal dynamics of milk composition of the precocial caviomorph Octodon degus (Rodentia: Octodontidae)
}

\author{
Dinámica temporal de la composición de la leche del caviomorfo precocial Octodon degus \\ (Rodentia: Octodentidae)
}

CLAUDIO VELOSO ${ }^{*}$ \& G.J. KENAGY ${ }^{2}$

\footnotetext{
${ }^{1}$ Departamento de Ciencias Ecológicas, Facultad de Ciencias, Universidad de Chile, Casilla 653, Santiago, Chile

${ }^{2}$ Department of Biology and Burke Museum, University of Washington, Seattle, Washington 98195, USA; * e-mail for corresponding author: clveloso@uchile.cl
}

\begin{abstract}
During lactation, both the nutritional and energetic requirements of suckling change gradually. These changes normally are accompanied by modifications in chemical composition of the milk. We investigated the temporal course of milk composition during lactation in a precocial caviomorph rodent, the "degu" (Octodon degus) under laboratory condition. Female degus were kept in laboratory during gestation and lactation and fed with commercial food pellets. Milk was collected at three stages of lactation: early (days 5-8, $\mathrm{n}=12$ ), middle (days $15-21, \mathrm{n}=7$ ) and late (days $26-40, \mathrm{n}=6$ ), and analyzed for protein, carbohydrates, lipids, ash, total solids and energy. On average, carbohydrates decreased from $3.1 \pm 0.3 \%$ (early) to $1.1 \pm 0.3 \%$ (late) during lactation; lipids, protein, ash, total solids and energy remained about the same. Lipids, the main component of the milk, were $17.3 \%$ and protein remained near $4.4 \%$. Over lactation, total energy concentration of milk remained near $4.0 \mathrm{~kJ} \mathrm{~mL}^{-1}$. The maintenance of milk composition during lactation may be related to the initially high energetic and nutritional requirements associated with a precocial reproductive mode.
\end{abstract}

Key words: degu, precocial, lactation, energy, lipids, milk composition.

\section{RESUMEN}

Durante la lactancia, tanto los requerimientos energéticos como nutricionales de las crías cambian gradualmente. Estos cambios normalmente van acompañados por modificaciones en la composición química de la leche. Se investigaron los cambios temporales de la composición de la leche durante la lactancia en el roedor caviomorfo precocial "degu" (Octodon degus) bajo condiciones de laboratorio. Las hembras de degu fueron mantenidas en el laboratorio durante preñez y lactancia, y fueron alimentadas con alimento comercial de conejo. La leche fue colectada en tres estados de lactancia: temprana (días 5-8, n =12), media (días 15-21, $\mathrm{n}=7$ ) y tardía (días $26-40, \mathrm{n}=6$ ), y analizadas para proteínas, hidratos de carbono, lípidos, ceniza, sólidos totales y energía. En promedio, los hidratos de carbono disminuyen desde 3,1 $\pm 0,3 \%$ (temprana) hasta $1,1 \pm$ $0,3 \%$ (tardía) durante la lactancia; mientras que, los lípidos, las proteínas, la ceniza, los sólidos totales y la energía se mantienen relativamente constantes. Los lípidos, el principal constituyente de la leche fue de 17,3 $\%$ y las proteínas correspondieron al 4,4\%. Durante la lactancia, la concentración de energía total de la leche permaneció cerca de los $4,0 \mathrm{~kJ} \mathrm{~mL}^{-1}$. La mantención de la composición de la leche durante la lactancia puede estar relacionada con los altos requerimientos energéticos y nutricionales asociados al modo reproductivo precocial.

Palabras clave: degu, precocial, lactancia, energía, lípidos, composición de la leche.

\section{INTRODUCTION}

Mammals are distinguished by two basic developmental strategies: altricial or precocial. Altricial mammals are characterized by short gestation and little somatic development of the newborn. On the contrary, precocial species experience a relatively long pregnancy, and somatic development of their newborn is more advanced (Derrickson 1992). Martin (1984) postulated that precocial animals should have more diluted milk than altricial, along with a 
different pattern of change in milk composition and production during lactation.

In mammals, milk is the only initial avenue for intake of matter and energy in the young. The increased energy expenditure associated with milk production in small mammals imposes maximal demands of nutrients and energy by mothers (Kenagy 1987, König et al. 1988). There is therefore, a strong selection pressure on physiological performance during lactation, as a result of the high energy turnover (Sadleir 1984). The energy intake and expenditure during lactation have been evaluated in a variety of rodent species (Millar 1979, Glazier 1985, König et al. 1988, Kenagy et al. 1990, Sikes 1995), but little is known about milk composition, its production and allocation to growth of pups in relation to the reproductive mode.

During lactation, both nutritional and energetic requirements of suckling young change gradually (Oftedal 1984), evidenced by changes in the proportion of lipids, proteins, and carbohydrates found in milk (Arman et al. 1974, Oftedal et al. 1983, Cork \& Dove 1989, Korine \& Arad 1999, Veloso et al. 2003). While lactating, rodents convert food eaten almost immediately into milk (Sadleir 1984). Interspecific variation in milk composition may reflect adaptation to differences in neonatal growth rates (Oftedal 1986).

Octodon degus is the most common Chilean diurnal rodent, of approximately $200 \mathrm{~g}$, and inhabits shrubland areas of arid central Chile. This species has a relatively long gestation period (three months), pups are precocial, and have a relatively short lactation period (30 days) (Rojas et al. 1977, Mann 1978, Morales 1982). Here we investigated the temporal pattern of milk composition during lactation in the precocial caviomorph rodent Octodon degus in laboratory conditions.

\section{MATERIAL AND METHODS}

Forty-four animals (38 female and 6 male) were captured between March and May near Lampa, central Chile $\left(33^{\circ} 17^{\prime} \mathrm{S}, 70^{\circ} 53^{\prime} \mathrm{W}\right.$, elevation $490 \mathrm{~m}$ ). All females were allowed to mate and give birth in captivity.

Females were maintained in large cages (1.6 x $0.8 \times 1.0 \mathrm{~m}$ ) in groups of 8-10 individuals with natural outdoor temperature and photoperiod; food and water were provided ad libitum. Between May and August females were inspected to determine vulvar opening, at which time they were placed singly in a breeding cage $(1.6 \times 1.6 \times 2.0 \mathrm{~m})$ with two or three males. After five days each female was separated in to an individual cage $(25 \times 30 \times 15$ $\mathrm{cm}$ ) and maintained during three months of pregnancy and one month of lactation under a 12L:12D photoperiod at $22 \pm 3{ }^{\circ} \mathrm{C}$. Only thirteen females $(34.2 \%)$ were pregnant.

Pregnant females received water and food ad libitum. Food was commercial rabbit pellet, and chemical composition is shown in Table 1, as analyzed by the Laboratory of Analytical Services at the Faculty of Agronomy, Pontificia Universidad Católica de Chile.

\section{TABLE 1}

Laboratory diet composition (\%) of lactating females of Octodon degus. Each component was determined twice; $\mathrm{NDF}=$ neutral detergent fiber; $\mathrm{ADF}=$ acid detergent fiber

Composición (\%) de la dieta de laboratorio de hembras lactantes de Octodon degus. Cada componente se estimó dos veces; $\mathrm{NDF}=$ fibra detergente neutra; $\mathrm{ADF}=$ fibra detergente ácida

\begin{tabular}{lc}
\hline Food component & Percentage \\
\hline Dry-matter & 90.6 \\
Ash & 10.8 \\
Crude fiber & 16.5 \\
Lipids & 3.0 \\
Proteins & 20.0 \\
Carbohydrates & 40.3 \\
NDF & 37.8 \\
ADF & 19.8 \\
\hline
\end{tabular}

Energy content $\left(\mathrm{kJ} \mathrm{g}^{-1}\right) 18.4$

Milk was collected from females, all of known parturition days, over the course of lactation, ranging from day five to day 40. A total of 25 useful samples was obtained from 13 individuals, from ten of which repeated samples were obtained at different stages of lactation on two to three occasions. To facilitate milk release and collection, females were injected intramuscularly with 2 I.U kg-1 oxytocin, diluted from a stock of 5 I.U. $\mathrm{mL}^{-1}$ (Sanderson S.A. Laboratories). Milk was collected by capillarity, using a Pasteur pipette from each of the eight teats, with gentle manual 
expression, until no further milk was apparent. All samples were obtained between 11:00 and 13:00 $\mathrm{h}$, after having separated the mother from the young for three hours. The sample volumes ranged from 50 to $200 \mu \mathrm{L}$ and were stored in $0.6 \mathrm{~mL}$ plastic tubes at $-20{ }^{\circ} \mathrm{C}$ until analysis.

Each sample was analyzed for: energy, total solid, protein, carbohydrate, lipid and ash. Total solid and ash were determined gravimetrically (Sartorius Supermicro S3D, to the nearest 0.5 $\mu \mathrm{g}$ ) by weighing a sample of $10 \mu \mathrm{L}$ and drying it at $100{ }^{\circ} \mathrm{C}$ for $24 \mathrm{~h}$ in a small aluminum container. Ash content (inorganic matter) was determined using the same sample by burning it twice in a small aluminum container in a muffle furnace (Nabertherm L3/P) at $560{ }^{\circ} \mathrm{C}$. Protein content was determined by analyzing $2 \mu \mathrm{L}$ of milk by the Coomassie Blue method (Bradford 1976) using bovine serum albumin as a standard. Carbohydrate content was determined on a $2 \mu \mathrm{L}$ sample by the anthrona method, using lactose as a standard (Yemm \& Willis 1954). All microvolumetric measurements were made with quantitative grade micropipettes. Lipid content was calculated for each sample by taking the difference between total solids and the sum of carbohydrates, proteins and ash. Finally, energy content of the milk was estimated from the measured milk composition using energetic equivalents of $24.6 \mathrm{~kJ} \mathrm{~g}^{-1}$ for proteins, $16.5 \mathrm{~kJ} \mathrm{~g}^{-1}$ for carbohydrates, and $38.1 \mathrm{~kJ} \mathrm{~g}^{-1}$ for lipids (Perrin 1958). Values of percentage concentration are presented on a wet-mass basis, and total energy content is expressed with respect to volume of whole milk.

Changes in milk composition over the course of lactation were analyzed by applying linear regression to the arcsine of square root transformed percentage data (Zar 1996). All values are mean $\pm 1 \mathrm{SD}$.

\section{RESULTS}

Parturition occurred between 12 September and 11 November. Mean pregnancy time was $87.9 \pm$ 2.6 days with a range of 86 to 93 days.

We obtained a total of 25 milk samples ranging from day 5 to day 40 of lactation between 16 September and 17 November. The temporal distribution of data falls into categories of early (5-8 days, $\mathrm{n}=12)$, middle (15-21 days, $\mathrm{n}=7)$ and late (26-40 days, $\mathrm{n}=6)$ lactation.
Total solids, ashes, lipid and protein in degu milk did not vary significantly during lactation (Fig. 1). Milk was relatively diluted with an average total solid concentration of $26.9 \pm 5.8$ $\%$ through all the lactation period. Lipids were the major constituent of degu milk, averaging $17.3 \pm 5.5 \%$ during lactation. Protein average concentration was $4.4 \pm 0.4 \%$ during lactation, while ash averaged $2.7 \pm 0.8 \%$. In contrast with other milk components carbohydrate concentration decreased significantly from 3.1 $\pm 0.3 \%$ to $1.0 \pm 0.3 \%$ from early to late lactation.

Total energy content did not change over time (Fig. 2), with an average value of $4.0 \pm 0.8$ $\mathrm{kJ} \mathrm{ml}^{-1}$. Throughout lactation lipids were the major source of milk energy, supplying $70.0 \%$ of total milk energy content, with protein providing $20.0 \%$, while carbohydrates ranged between $13.2 \%$ (early lactation) and $5.1 \%$ (late lactation) of total energy.

\section{DISCUSSION}

In Octodon degus both energy concentration and nutrient composition of milk were practically constant during lactation. This pattern differs from the normal variation in milk concentration found in altricial rodents and mammals in general, where total solids increase with time principally due to increase of lipids (Oftedal 1984, Veloso et al. 2003). Changes in milk concentration, and particularly in lipid concentration, have been associated with increasing energy and nutrient demands of pups during development (Baverstock et al. 1976). The relatively high initial lipid concentration of degu milk in early lactation may be related with its precocial condition and the high energy demand during the first days of life, when pups consume only milk.

Precocial species produce diluted milk, because their pups begin to eat solid food early in ontogeny, and may thus supplement their energy requirements (Martin 1984). Nevertheless Derrickson et al. (1996) found different milk concentration in two precocial rodents: diluted in the caviomorph Kerodon rupestris and concentrated in the murid Acomys cahirinus. Octodon degus milk concentration ranged between both species. Among caviomorphs, Oftedal (1984) show in two 


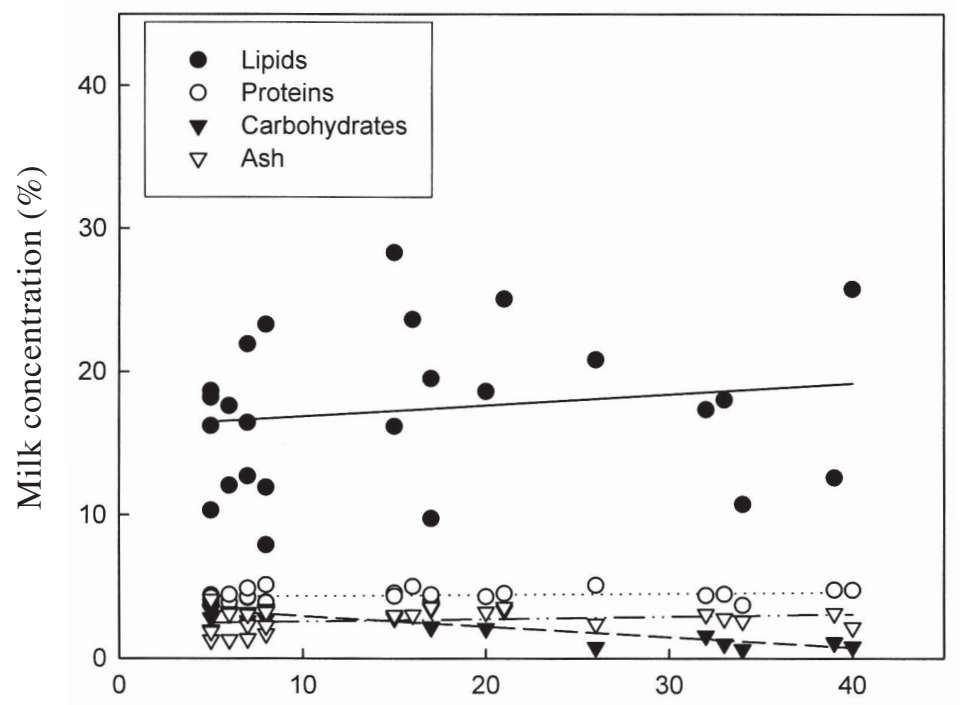

Lactation time (days)

Fig. 1: Lipids, proteins, carbohydrates and ash concentration in Octodon degus milk during lactation. The lines fitted to the data points are linear regressions, as follows, from top to bottom: lipids, $\mathrm{y}=23.424+0.057 \mathrm{x}\left(\mathrm{r}^{2}=-0.02, \mathrm{P}=0.45\right)$; proteins, $\mathrm{y}=11.874+0.012 \mathrm{x}\left(\mathrm{r}^{2}=0.03, \mathrm{P}=\right.$ $0.21)$; carbohydrates, $\mathrm{y}=11.338-0.154 \mathrm{x}\left(\mathrm{r}^{2}=0.78, \mathrm{P}<0.000001\right)$; ash, $\mathrm{y}=8.702+0.036 \mathrm{x}\left(\mathrm{r}^{2}=\right.$ $0.04, \mathrm{P}<0.16)$.

Concentración de lípidos, proteínas, hidratos de carbono y ceniza en la leche de Octodon degus durante la lactancia. Las líneas asociadas a los puntos corresponden a regresiones lineales, desde arriba hacia abajo: lípidos, $\mathrm{y}=23,424+0,057 \mathrm{x}\left(\mathrm{r}^{2}\right.$ $=-0,02 ; \mathrm{P}=0,45)$; proteínas, $\mathrm{y}=11,874+0,012 \mathrm{x}\left(\mathrm{r}^{2}=0,03 ; \mathrm{P}=0,21\right)$; hidratos de carbono, $\mathrm{y}=11,338-0,154 \mathrm{x}\left(\mathrm{r}^{2}=\right.$ $0,78 ; \mathrm{P}<0,000001)$; ceniza, $\mathrm{y}=8,702+0,036\left(\mathrm{r}^{2}=0,04 ; \mathrm{P}=0,16\right)$.

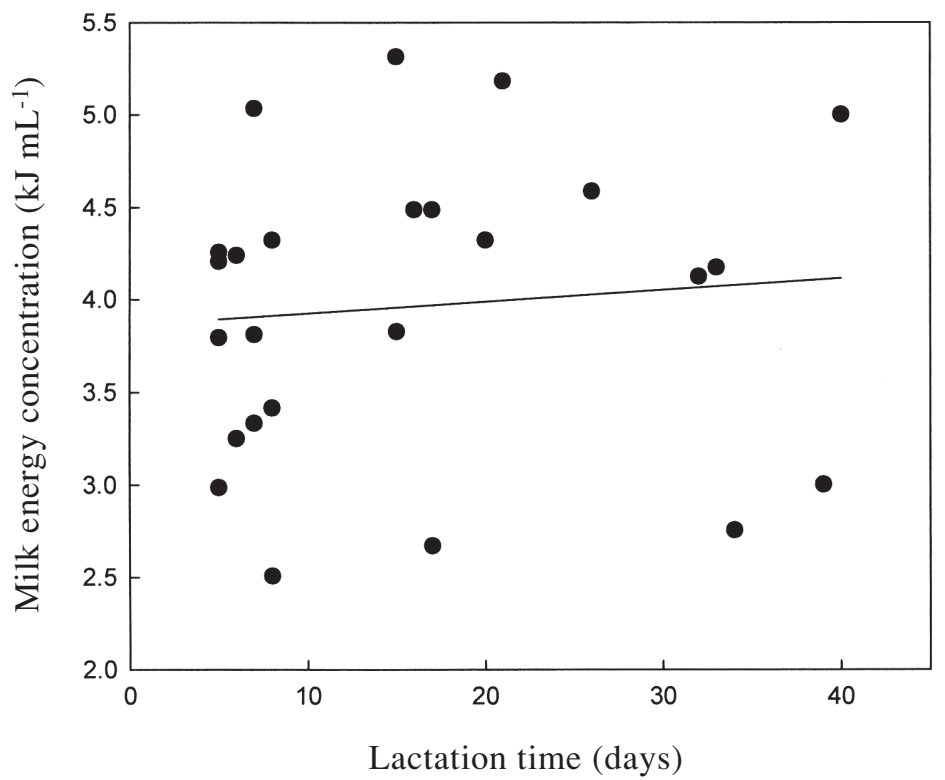

Fig. 2: Total milk energy concentration during lactation of Octodon degus. The line is described by the regression: $\mathrm{y}=3.845+0.009 \mathrm{x}\left(\mathrm{r}^{2}=-0.03, \mathrm{P}=0.5\right)$, where $\mathrm{y}$ is energy concentration of whole milk in $\mathrm{kJ} \mathrm{mL}^{-1}$.

Concentración total de energía durante la lactancia de Octodon degus. La línea es descrita por la regresión: y = 3,845 + $0,009 \mathrm{x}\left(\mathrm{r}^{2}=-0,03 ; \mathrm{P}=0,5\right)$, donde y es el contenido de energía de la leche en $\mathrm{kJ} \mathrm{mL}^{-1}$. 
species (Cavia porcellus and Chinchilla lanigera) similar concentrations to those found in $K$. rupestris. However, O. degus milk was more concentrated than in the other three caviomorph species. An important point is that C. porcellus (Künkelle \& Trillmich 1996), K. rupestris and $C$. lanigera pups can eat and digest solid food during early lacation (at 3 days of life), however $O$. degus pups start to digest solid food not until the $15^{\text {th }}$ day of lactation. In this context, the highest concentration observed in $O$. degus milk should be associated with a major dependence of the maternal nutrition in relation with the other three caviomorph species shown in Table 2.

TABLE 2

Milk composition (\%) in four caviomorph rodents during mid lactation

Composición de la leche $(\%)$ de cuatro roedores caviomorfos durante lactancia media

\begin{tabular}{lccrc}
\hline Species & Proteins & $\begin{array}{c}\text { Carbo- } \\
\text { hydrates }\end{array}$ & Lipids & $\begin{array}{c}\text { Total } \\
\text { solids }\end{array}$ \\
\hline Octodon degus $^{a}$ & 4.4 & 2.7 & 20.1 & 30.5 \\
Cavia porcellus $^{b}$ & 6.3 & 4.8 & 5.7 & 17.5 \\
Chinchilla laniger $^{b}$ & 7.3 & 1.7 & 11.2 & 20.2 \\
Kerodon rupestris $^{c}$ & 6.6 & 5.2 & 7.5 & 20.0 \\
\hline
\end{tabular}

a This study; 'b Oftedal (1984); ${ }^{\mathrm{C}}$ Derrikson et al. (1996)

Within the lineage of caviomorph rodents, the milk of $O$. degus has the highest lipid and total solid concentration of four species shown in Table 2, and the lowest proportion of protein and carbohydrates. Octodon degus is a precocial species, but pups cannot control body temperature before twenty days and do not digest solid food until the fifteen day of lactation (Veloso 1997). Apparently degus require a high energy and nutrient supply from milk during early lactation, increasing gradually the importance of solid food until late lactation. This conclusion is enforced by changes in disaccharidase activity (decrease of lactose and increase of sucrase activity) during lactation time (Sabat \& Veloso 2003), and with the significant reduction in milk carbohydrate concentration observed during lactation, both starting at day 15 approximately.

In short, the pattern of milk concentration observed in $O$. degus is associated with the precocial life of this rodent.

\section{ACKNOWLEDGEMENTS}

This work is dedicated to the memory of Mario "El Profe" Rosenmann. We thank Bárbara Saavedra who made helpful comments and suggestions on an earlier draft of the manuscript. This work was supported by FONDECYT grant 2950017.

\section{LITERATURE CITED}

ARMAN P, RNB KAY, ED GOODALL \& GAM SHARMAN (1974) The composition and yield of milk from captive red deer (Cervus elaphus L.). Journal of Reproduction and Fertility 37: 67-84.

BANKS W, JL CLAPPERTON, ME FERRIE \& AG WILSON (1976) Effect of feeding fat to dairy cows receiving a fat-deficient basal diet 1 . Milk yield and composition. Journal of. Dairy Research 43: 213-218.

BAVERSTOCK PR, L SPENCER \& C POLLARD (1976) Water balance of small lactating rodents. II. Concentration and composition of milk of females on ad libitum and restricted water intakes. Comparative Biochemistry and Physiology A 53: 47-52.

BERNARD JK \& WW MCNEILL (1991) Effect of high fiber energy supplements on nutrient digestibility and milk production of lactating dairy cows. Journal of Dairy Science 74: 991-995.

BRADFORD MM (1976) A rapid and sensitive method for the quantitation of microgram quantities of protein utilizing the principle of protein-dye binding. Analytical Biochemistry 72: 248-254.

CORK SJ \& H DOVE (1989) Lactation in the tammar wallaby (Macropus eugenii). II. Intake of milk components and maternal allocation of energy. Journal of Zoology, London 219: 399-409.

DERRICKSON EM (1992) Comparative reproductive strategies of altricial and precocial eutherian mammals. Functional Ecology 6: 57-65.

DERRICKSON EM, N JERRARD \& O OFTEDAL (1996) Milk composition of two precocial, arid-dwelling rodents, Kerodon rupestris and Acomys cahirinus. Physiological Zoology 69: 1402-1418.

FORSUM E \& B LÖNNERDAL (1980) Effect of protein intake on protein and nitrogen composition of breast milk. American Journal of Clinical Nutrition 33: 1809-1813.

GLAZIER DS (1985) Energetics of litter size in five species of Peromyscus with generalizations for other mammals. Journal of Mammalogy 66: 629642.

KENAGY GJ (1987) Energy allocation for reproduction in the golden-mantled ground squirrel. Symposia of the Zoological Society of London 57: 259-273.

KENAGY GJ, D MASMAN, SM SHARBAUGH. \& KA NAGY (1990) Energy expenditure during lactation in relation to litter size in free-living goldenmantled ground squirrels. Journal of Animal Ecology 59: 73-88.

KOLDOVSKY O (1995) Do hormones in milk affect the function of neonatal intestine? American Zoologist 35: 446-454.

KÖNIG B, J RIESTER \& H MARKL (1988) Maternal care in house mice (Mus musculus): II. The energy cost of lactation as function of litter size. Journal of Zoology, London 216: 195-210. 
KÜNKELLE J \& F TRILLMICH (1997) Are precocial young cheaper? Lactation energetics in the guinea pig. Physiological Zoology 70: 589-596.

MALTZ E \& A SHKOLNIK (1984) Lactational strategies of desert ruminants: the bedouin goat, ibex and desert gazelle. Symposia of the Zoological Society of London 51: 193-213.

MANN G (1978) Los pequeños mamíferos de Chile. Gayana Zoología (Chile) 40: 1-342.

MARTIN RD (1984) Scalling effects and adaptative strategies in mammalian lactation. Symposia of the Zoological Society of London 51: 87-117.

MESERVE PL, R MARTIN \& J RODRÍGUEZ (1984) Comparative ecology of the caviomorph rodent Octodon degus in two Chilean mediterranean-type comunities. Revista Chilena de Historia Natural 57: 79-89.

MILLAR JS (1979) Energetics of lactation in Peromyscus maniculatus. Canadian Journal of Zoology 57: 1015-1019.

MORALES B (1982) Estado de avance en el estudio de la reproducción y embriología de un mamífero chileno. Museo Nacional de Historia Natural, Publicación Ocasional (Chile) 38: 145-164.

OFTEDAL OT (1984) Body size and reproductive strategy as correlates of milk energy output in lactating mammals. Acta Zoologica Fennica 171: 183-186.

OFTEDAL OT (1986) Growth rate and milk composition: a critical appraisal. Ross Laboratories, Columbus, Ohio, USA.

OFTEDAL OT, HF HINTZ \& HF SCHRYVER (1983) Lactation in the horse: milk composition and intake by foals. Journal of Nutrition 113: 2196-2206.

PERRIN DR (1958) The caloric value of milk of different species. Journal of Dairy Research 25: 215-220.

ROJAS M, O RIVERA, G MONTENEGRO \& C BARROS (1977) Algunas observaciones en la reproducción de la hembra silvestre de Octodon degus, Molina y su posible relación con la fenología de la vegetación. Medio Ambiente (Chile) 3: 78-82.

SABAT P \& C VELOSO (2003) Ontogenetic development of intestinal disaccharidases in the precocial rodent Octodon degus (Octodontidae). Comparative Biochemistry and Physiology A 134: 393-397.

SADLEIR RMFS (1984) Ecological consequences of lactation. Acta Zoologica Fennica 171: 179182.

SIKES RS (1995) Cost of lactation and optimal litter size in northern grasshoper mice (Onychomys leucogaster). Journal of Mammalogy 76: 348-357.

VELOSO C (1997) Energética reproductiva del roedor precocial herbívoro Octodon degus (Rodentia: Octodontidae). Doctoral Dissertation, Facultad de Ciencias, Universidad de Chile, Santiago, Chile. $165 \mathrm{pp}$.

VELOSO C \& F BOZINOVIC (2000) Effect of food quality on the energetics of reproduction in a precocial rodent, Octodon degus. Journal of Mammalogy 81: 971-978.

VELOSO C, NJ PLACE \& GJ KENAGY (2003) Milk composition of free-living yellow-pine chipmunks (Tamias amoenus): temporal variation during lactation. Comparative Biochemistry and Physiology A 134: 387-392.

YEMM EW \& AJ WILLIS (1954) The estimation of carbohydrates in plant extracts by anthrone. Biochemistry 57: 508-514.

ZAR JH (1996) Biostatistical analysis. Prentice Hall, Upper Saddle River, New Jersey. USA. 662 pp.

ZIMMERMAN CA, AH RAKES, RD JAQUETTE, BA HOPKINS \& WJ CROOM (1991) Effects of protein level and forage source on milk production and composition in early lactation dairy cows. Journal of Dairy Science 74: 980-990. 